\title{
SOME OBSERVATIONS ON THE METABOLISM OF D-GALACTOSE IN NORMAL MAN
}

\author{
By STANTON SEGAL AND ALBERTA BLAIR
}

(From the Clinical Endocrinology Branch, National Institute of Arthritis and Mctabolic Diseases, Bethesda, Md.)

(Submitted for publication May 8, 1961 ; accepted July 17, 1961)

For many years clinical interest in D-galactose centered about the usefulness of galactose tolerance tests in the diagnosis of impaired liver function. Several investigators, employing an intravenous galactose tolerance test, have reported their results (1-3). The monograph by Stenstam (4) is perhaps the most extensive analysis of both the oral and intravenous tolerance test yet reported. In all of these studies the parameter for measurement of galactose metabolism has been the disappearance rate of the sugar from blood or the urinary excretion of the sugar for an arbitrary time interval.

More recently research in galactose metabolism has had as its focal point the disease, congenital galactosemia. Kalckar and Maxwell, and their associates (5-7) have contributed to the delineation of the pathways of galactose metabolism and have pinpointed the enzymatic defect in galactosemia $(8,9)$. Other investigators have reported that certain steroids as well as menthol are able to prevent the depression of galactose oxidation in liver slices and homogenates caused by the metabolism of ethanol and aldehydes (10-12). The administration of progesterone (13) and menthol (12) has enhanced the ability of galactosemic subjects to oxidize galactose to $\mathrm{CO}_{2}$.

Because of the latter experiments it became important to delineate the physiologic disposition and metabolic fate of $\mathrm{C}^{14}$-galactose in normal subjects. This report presents the results of experiments performed for this purpose. Observations have been made of the effect of progesterone. menthol, and ethanol on galactose-1-C $\mathrm{C}^{14}$ oxidation.

\section{METHODS}

Sixteen intravenous infusions of galactose-1- $C^{14}$ were carried out in 6 normal male volunteer subjects whose ages ranged from 18 to 22 . These subjects were maintained on a $300 \mathrm{~g}$ carbohydrate diet and had normal glucose tolerance as determined by the method of Amatuzio, Stutzman. Vanderbilt and Nesbitt (14). All experi- ments were performed after an overnight fast which was continued during the 5 -hour period of study.

All of the above subjects received $5 \mu \mathrm{c}$ of galactose$1-C^{14}$ either as a tracer of $1.05 \mathrm{mg}$ or mixed with either 10 or $20 \mathrm{~g}$ of unlabeled galactose present in 20 per cent solution. In two studies $50 \mathrm{mg}$ per day i.m. progesterone and in another experiment $750 \mathrm{mg}$ per day p.o. menthol were administered for 5 and 3 days, respectively, prior to the isotope infusion. When ethanol was given, 10 or $20 \mathrm{ml}$ of absolute ethanol was diluted with an equal volume of water and ingested, p.o., 5 minutes prior to the radioactive galactose infusion. At various time intervals after the infusion, expired air for $\mathrm{C}^{14} \mathrm{O}_{2}$ analysis was collected in Douglas bags and blood was drawn for galactose and glucose analysis. Urine was collected for 24 hours for determination of radioactivity, and in some experiments in which large quantities of galactose were given, assays were performed for reducing substance and glucose oxidase-reacting material.

Galactose-1-C $\mathrm{C}^{14}$ (specific activity $4.72 \mu \mathrm{c}$ per $\mathrm{mg}$ ) was purchased from Dr. H. Isbell of the National Bureau of Standards and prepared for intravenous use as a solution of $1 \mu \mathrm{c}$ per $\mathrm{ml}$ of normal saline by the radiopharmacy of the National Institutes of Health. Unlabeled galactose was purchased from the Pfanstiehl Co. and prepared for i.v. use as a 20 per cent solution by the NIH pharmacy. These solutions were sterile and pyrogenfree. USP absolute ethanol was used. Progesterone in oil was the commercial preparation of Eli Lilly and Co. L-menthol was given orally as a 25 per cent peanut oil solution in gelatin capsules containing $250 \mathrm{mg}$ of the drug. The Na pyruvate used was purchased from Schwartz Biochemical Co. and prepared for use as a 10 per cent solution in normal saline.

Carbon dioxide was assayed by the method of Fredrickson and Ono (15) and the $\mathrm{C}^{14} \mathrm{O}_{2}$ in Hyamine assayed in a Packard Tri-Carb liquid scintillation spectrometer counting at 54 per cent efficiency. Blood glucose in filtrates prepared by the Somogyi procedure and urine glucose were assayed with glucose oxidase. ${ }^{1}$ Galactose was estimated as the difference between total reducing substance by the Nelson method (16) and glucose oxidasepositive material. Blood was assayed for radioactivity as described previously (17). Glucose was isolated from blood by the method of Blair and Segal (18). Radioactive galactose in blood was estimated by the isotope dilution technic as follows. To a 1:10 Somogyi blood

${ }^{1}$ Glucostat reagent purchased from Worthington Biochemical Co., Freehold, N. J. 
filtrate made from $20 \mathrm{ml}$ whole blood was added a known amount (approximately $50 \mathrm{mg}$ ) of galactose. The filtrate was evaporated to $3 \mathrm{ml}$. To this was added an equal volume of concentrated nitric acid. This was heated for 90 minutes in a boiling water bath and then placed overnight in a refrigerator at $4^{\circ} \mathrm{C}$. The mucic acid crystallized out of solution and was recrystallized from hot water. Both gluconate and mucic acid were combusted to $\mathrm{CO}_{2}$ by the method of Van Slyke, Plazin and Weisiger (19). The $\mathrm{BaCO}_{3}$ thus obtained was treated with acid to liberate $\mathrm{CO}_{2}$ which was trapped in Hyamine and counted by the scintillation technic (20). Urine- $\mathrm{C}^{14}$ was assayed as previously described (21).

Two laboratory personnel, one male and one female, ages 33 and 35, respectively, donated blood from which leukocytes were prepared by the method of Skoog and Beck (22). The incubation procedure was similar to that already reported (23). Human liver for in vitro study was obtained at surgery from a 29 -year old male with metastatic islet cell carcinoma. Tumor was present in the liver but none was observed macroscopically in the segments used to prepare the tissue slices for the in vitro study.

\section{RESULTS}

The effect of increasing the quantity of sugar injected on oxidation of galactose-1-C $C^{14}$ to $\mathrm{C}^{1+} \mathrm{O}_{2}$. The radioactive sugar was metabolized to labeled $\mathrm{CO}_{2}$ as shown for a tracer amount in Figure 1. The control curve in the upper part of Figure 1 is similar to that observed after glucose-1-C $\mathrm{C}^{14}$ administration (24). Table I reveals the per cent of the administered $\mathrm{C}^{14}$ found in expired air at hourly intervals after injection of the isotope. When the amount of injected galactose was about $1 \mathrm{mg}, 31$ to 35 per cent of the $\mathrm{C}^{14}$ dose was in ex-

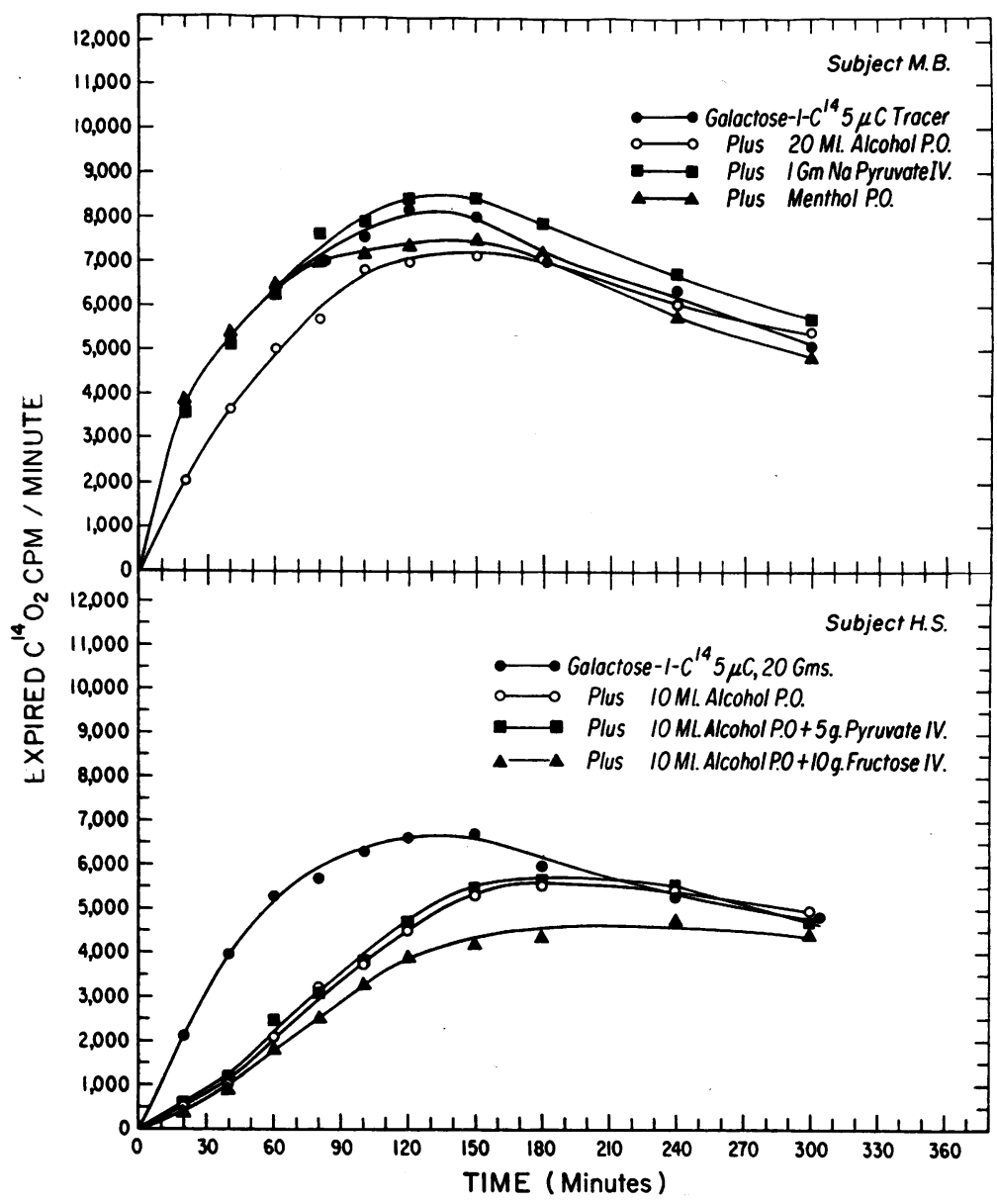

Fig. 1. UPPER PORTION IS THE EXPIRED $\mathrm{C}^{14} \mathrm{O}_{2}$ AFTER I.v. ADMINISTRATION OF A TRACER QUANTITY OF GALACTOSE-1-C ${ }^{14}$ IN A NORMal SUBJECT. Alcohol refers to ethanol. Lower portion is the $\mathrm{C}^{14} \mathrm{O}_{2}$ excretion curves after administration of $20 \mathrm{~g}$ galactose containing the same amount of galactose-1- $\mathrm{C}^{14}$ as given in the tracer experiments. 
TABLE I

The extent of oxidation of galactose-1-C $C^{14}$ after intravenous injection into normal subjects

\begin{tabular}{|c|c|c|c|c|c|c|c|c|}
\hline \multirow[b]{2}{*}{ Subj. } & \multirow[b]{2}{*}{ Amt. of sugar } & \multirow[b]{2}{*}{ Exptal. additions } & \multirow{2}{*}{$\underset{\text { excret. }}{\mathrm{CO}_{2}}$} & \multicolumn{5}{|c|}{$\begin{array}{l}\text { Administered } \mathrm{C}^{14} \text { in expired air } \\
\text { Minutes after injection }\end{array}$} \\
\hline & & & & 60 & 120 & 180 & 240 & 300 \\
\hline & & & mmoles/min & & & $\%$ & & \\
\hline S.K. & $\begin{array}{l}0.00106 \\
0.00106\end{array}$ & $\begin{array}{l}\text { None } \\
\text { Progesterone }\end{array}$ & $\begin{array}{l}10.8 \\
10.8\end{array}$ & $\begin{array}{l}3.86 \\
3.84\end{array}$ & $\begin{array}{l}10.17 \\
10.53\end{array}$ & $\begin{array}{l}17.60 \\
18.23\end{array}$ & $\begin{array}{l}25.08 \\
25.75\end{array}$ & $\begin{array}{l}31.71 \\
32.42\end{array}$ \\
\hline J.F. & $\begin{array}{l}0.00106 \\
0.00106\end{array}$ & $\begin{array}{l}\text { None } \\
\text { Progesterone }\end{array}$ & $\begin{array}{l}12.2 \\
12.7\end{array}$ & $\begin{array}{l}4.31 \\
5.49\end{array}$ & $\begin{array}{l}12.54 \\
14.75\end{array}$ & $\begin{array}{l}21.25 \\
24.41\end{array}$ & $\begin{array}{l}28.77 \\
32.85\end{array}$ & $\begin{array}{l}35.23 \\
39.85\end{array}$ \\
\hline M.B. & $\begin{array}{l}0.00106 \\
0.00106 \\
0.00106 \\
0.00106\end{array}$ & $\begin{array}{l}\text { None } \\
\text { Menthol } \\
\text { Pyruvate, } 1 \mathrm{~g} \\
\text { Ethanol, } 20 \mathrm{ml}\end{array}$ & $\begin{array}{r}9.9 \\
10.0 \\
10.6 \\
9.6\end{array}$ & $\begin{array}{l}4.24 \\
4.24 \\
4.24 \\
2.80\end{array}$ & $\begin{array}{r}11.87 \\
11.53 \\
12.13 \\
9.19\end{array}$ & $\begin{array}{l}20.09 \\
19.14 \\
20.69 \\
16.57\end{array}$ & $\begin{array}{l}27.19 \\
25.80 \\
28.22 \\
23.50\end{array}$ & $\begin{array}{l}33.07 \\
31.30 \\
34.58 \\
29.43\end{array}$ \\
\hline \multirow[t]{2}{*}{ D.S. } & $\begin{array}{l}10.0 \\
10.0 \\
\text { Glucose-1-C } 14\end{array}$ & $\begin{array}{l}\text { None } \\
\text { Ethanol, } 10 \mathrm{ml}\end{array}$ & $\begin{array}{l}10.3 \\
10.5\end{array}$ & $\begin{array}{l}2.01 \\
1.02\end{array}$ & $\begin{array}{l}7.20 \\
5.23\end{array}$ & $\begin{array}{l}14.40 \\
11.62\end{array}$ & $\begin{array}{l}22.09 \\
18.45\end{array}$ & $\begin{array}{l}29.11 \\
24.93\end{array}$ \\
\hline & $\begin{array}{l}0.0018 \\
0.0018\end{array}$ & $\begin{array}{l}\text { None } \\
\text { Ethanol, } 10 \mathrm{ml}\end{array}$ & $\begin{array}{l}10.6 \\
11.1\end{array}$ & $\begin{array}{l}4.02 \\
4.69\end{array}$ & $\begin{array}{l}12.50 \\
14.01\end{array}$ & $\begin{array}{l}21.61 \\
23.42\end{array}$ & $\begin{array}{l}29.31 \\
31.58\end{array}$ & $\begin{array}{l}35.56 \\
38.54\end{array}$ \\
\hline D.P. & $\begin{array}{l}20.0 \\
20.0\end{array}$ & $\begin{array}{l}\text { None } \\
\text { Ethanol, } 20 \mathrm{ml}\end{array}$ & $\begin{array}{l}11.7 \\
13.0\end{array}$ & $\begin{array}{l}1.85 \\
0.77\end{array}$ & $\begin{array}{l}6.66 \\
3.19\end{array}$ & $\begin{array}{r}12.75 \\
7.93\end{array}$ & $\begin{array}{l}19.10 \\
14.03\end{array}$ & $\begin{array}{l}25.24 \\
20.11\end{array}$ \\
\hline \multirow[t]{3}{*}{ H.S. } & $\begin{array}{l}20.0 \\
20.0 \\
20.0\end{array}$ & \multirow{3}{*}{$\begin{array}{l}\text { None } \\
\text { Ethanol, } 10 \mathrm{ml} \\
\text { Ethanol, } 10 \mathrm{ml} \\
\text { Fructose, } 10 \mathrm{~g} \\
\text { Ethanol, } 10 \mathrm{ml} \\
\text { Pyruvate, } 5 \mathrm{~g}\end{array}$} & $\begin{array}{l}10.1 \\
10.7\end{array}$ & $\begin{array}{l}3.08 \\
0.94\end{array}$ & $\begin{array}{l}9.49 \\
4.47\end{array}$ & $\begin{array}{r}16.37 \\
9.98\end{array}$ & $\begin{array}{l}22.51 \\
15.81\end{array}$ & $\begin{array}{l}27.78 \\
21.27\end{array}$ \\
\hline & 20.0 & & 9.7 & 0.81 & 3.84 & 8.30 & 13.14 & 17.84 \\
\hline & & & 10.5 & 1.02 & 4.73 & 10.44 & 16.41 & 21.83 \\
\hline
\end{tabular}

pired $\mathrm{CO}_{2}$ within 5 hours. This corresponds quite closely with the amount of $\mathrm{C}^{14} \mathrm{O}_{2}$ excreted after glucose-1- $\mathrm{C}^{14}$ injection as reported previously (24) and shown also in Subject D.S., Table I. The injection of 10 and $20 \mathrm{~g}$ sugar containing an identical amount of radioactivity resulted in a slight reduction of the per cent of the injected $\mathrm{C}^{14}$ excreted in expired air, as shown in Table $\mathrm{I}$. Subject D.S., given $10 \mathrm{~g}$, excreted 29 per cent, and Subjects D.P. and H.S., given $20 \mathrm{~g}$, excreted 25 and 28 per cent of the radioactivity, respectively, in 5 hours.

The effect of increasing the amount of injected sugar is most striking when one compares the per cent $\mathrm{C}^{14}$ excreted at 1 hour with the values for the tracer studies. The lower portion of Figure 1 shows the $\mathrm{C}^{14} \mathrm{O}_{2}$ excretion curve after a $20 \mathrm{~g}$ infusion in Subject H.S. The initial rate of $\mathrm{C}^{14} \mathrm{O}_{2}$ production is about 40 per cent slower than that seen for the tracer study in Figure 1. With time, however, the $\mathrm{C}^{14} \mathrm{O}_{2}$ excretion after a load approaches that seen after a tracer quantity. Considering the fact that the specific activity of the injected galactose is lowered 10- and 20-thousand- fold in the load experiments, it appears that the system has a large capacity for metabolizing galactose. The fact that the $\mathrm{C}^{14} \mathrm{O}_{2}$ excretion is somewhat lower after a load suggests that the system is beginning to be saturated, for it would be expected that the per cent of substrate metabolized remains constant with increasing concentration until the point of saturation where the value would then decrease. The effect on expired $\mathrm{C}^{14} \mathrm{O}_{2}$ observed with increasing quantity of injected galactose is in marked contrast to that observed with D-ribose, where a marked decrease in oxidation occurred upon increasing the sugar given from a tracer to $20 \mathrm{~g}$ (17).

Effect of progesterone and menthol on galactose oxidation. It has been reported that progesterone administration to three galactosemic children and menthol administration in two others enhanced their ability to oxidize a tracer quantity of labeled galactose $(12,13)$. In these experiments, during control periods, virtually no $\mathrm{C}^{14} \mathrm{O}_{2}$ was produced, whereas after the administration of these drugs, from 7 to 17 per cent of the $\mathrm{C}^{14}$ injected appeared in $\mathrm{CO}_{2}$ in 5 hours. Three studies, two 
with progesterone and one with menthol, have now been performed in normal subjects, and the results are shown in Table I and Figure 1. A problem presented itself in these studies. Whereas, in the galactosemic children in whom the capacity for metabolizing galactose to $\mathrm{CO}_{2}$ is essentially nil and the effects of a drug stimulating oxidation may be easily seen, in the normal there is a baseline of rapid and extensive metabolism which is probably maximal. Fluctuations in this baseline could make interpretation of the drug studies difficult. In Subject S.K. the per cent of the $\mathrm{C}^{14}$ given that appeared in expired air was virtually identical before and after progesterone administration. Subject J.F. showed a slight increase after the drug. Subject M.B., whose postmenthol excretion curve is seen in Figure 1, had no stimulatory effect of the drug. The results indicate that these drugs do not have an effect on galactose metabolism in a normal subject.

Caution must be exercised, however, in comparing the effect of these drugs in post-pubertal normal subjects and children. Because of the problems involved, we have not performed these experiments with radioisotopes in normal children.

Effect of ethyl alcohol on galactose oxidation. Stenstam (4) has demonstrated very clearly in the human that ethyl alcohol impairs the clearance of administered galactose from blood. Several reports have appeared which demonstrate in vitro that ethanol inhibits galactose metabolism and that this effect is due to changes in intracellular reduced diphosphopyridine nucleotide (DPNH) $(11,25,26)$.

The present studies reveal that small amounts of ethanol may markedly inhibit the metabolism of galactose-1-C $\mathrm{C}^{14}$ to $\mathrm{C}^{14} \mathrm{O}_{2}$. These results are tabulated in Table I. Figure 1 demonstrates this inhibition in a tracer study in Subject M.B. The potency of the effect is brought out here, since this reveals the inhibition of metabolism of $1 \mathrm{mg}$ in a system that has a capacity for metabolizing many thousands of milligrams. The effect of ethanol was greater in the loading experiments with 10 and $20 \mathrm{~g}$. Figure 1 also shows the marked inhibition of appearance of $\mathrm{C}^{14} \mathrm{O}_{2}$ in a study with 20 $\mathrm{g}$ of the sugar. This effect of ethanol is not seen when $\mathrm{C}^{14}$ glucose is injected, as is shown in Table I, Subject D.S.

Smith and Newman (27) have demonstrated in the rat that injected pyruvate decreases the high levels of DPNH generated in liver during ethanol administration by being reduced to lactate with $\mathrm{DPNH}$ as a cofactor. Two experiments were therefore performed on the effect of pyruvate on galactose-1-C $\mathrm{C}^{14}$ oxidation. In the first (Figure 1$), 1 \mathrm{~g}$ of pyruvate was given i.v. in the absence of ethanol to see whether the normal metabolism could be stimulated. Little or no effect was observed. In the second, shown in the lower section of Figure 1, an attempt was made to reverse the effect of $10 \mathrm{ml}$ of ethanol by injecting $5 \mathrm{~g}$ of sodium pyruvate. This amount of pyruvate failed to overcome the inhibition. Because the principal fate of pyruvate in man may be oxidation rather than the conversion to lactate, which would be needed for alteration of DPNH levels, a pyruvategenerating system, involving fructose metabolism, was employed (28). Figure 1 also demonstrates that $10 \mathrm{~g}$ of fructose i.v. was also unable to overcome the ethanol effect.

The disappearance of $C^{14}$ and galactose from blood and the conversion of galactose to glucose. Figure 2 demonstrates the change with time in whole blood $\mathrm{C}^{14}$ after a tracer dose of galactose1-C $\mathrm{C}^{14}$ was given to Subjects M.B. and J.F. The inset shows the decrease in chemically determined galactose in blood of M.B. after a $5 \mathrm{~g}$ infusion. Whereas there was no detectable galactose in blood 15 minutes after the $5 \mathrm{~g}$ infusion, at the same time and for many minutes thereafter, much $\mathrm{C}^{14}$ was present in the tracer experiment. The rate of decrease of $\mathrm{C}^{14}$ was very much slower than that of galactose itself.

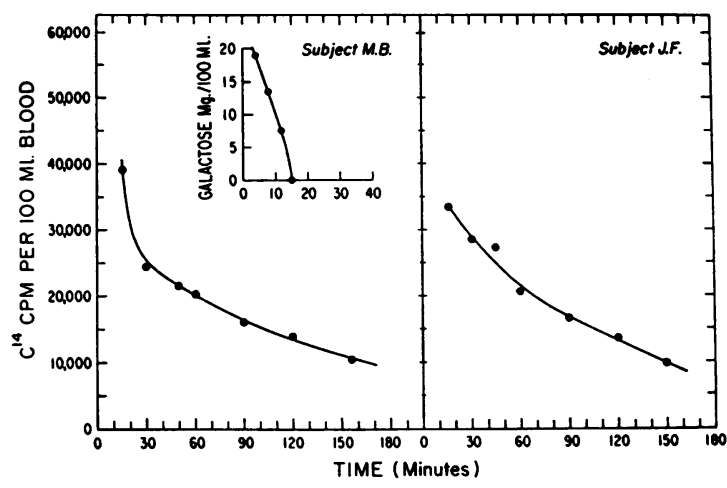

Fig. 2. The change in blood $\mathrm{C}^{14}$ with trme After LABELED GALACTOSE INJECTION. The inset shows the disappearance from blood of chemically determined galactose after a $5 \mathrm{~g}$ injection. 
TABLE II

Distribution of $C^{14}$ in blood after galactose-1- $C^{14}$ and glucose-1-C ${ }^{14}$ administration

\begin{tabular}{lrccc}
\hline & & \multicolumn{3}{c}{$\mathrm{C}^{14}$ in blood } \\
\cline { 3 - 5 } $\begin{array}{c}\text { Sugar injected } \\
\text { and subject }\end{array}$ & $\begin{array}{c}\text { Time after } \\
\text { inject. }\end{array}$ & Total C14 & Galactose C 14 & Glucose C14* \\
\hline & $\min$ & $d p m / 100 \mathrm{ml}$ & $d p m / 100 \mathrm{ml}$ & $d p m / 100 \mathrm{ml}$ \\
Galactose-1-C14 & 30 & 48,400 & 2,723 & 18,485 \\
M.B. & 121 & 21,000 & 223 & 7,305 \\
& 15 & 43,400 & 3,402 & 12,904 \\
J.F. & 96 & 20,600 & 657 & 5,980 \\
& & & & \\
Glucose-1-C 14 & 30 & 35,600 & & 29,680 \\
D.S. & 90 & 22,380 & & 10,250 \\
& & & &
\end{tabular}

* Corrected for adsorption of radioactive galactose (18).

The latter fact suggested that metabolites of galactose were present in blood. Since the pathway of galactose metabolism involves conversion to glucose, two experiments were carried out to ascertain how much of $\mathrm{C}^{14}$ in blood after a tracer injection was in glucose or galactose. The galactose- $\mathrm{C}^{14}$ was isolated as mucic acid by a carrierdilution technic, and glucose as gluconate. Table II contains the results of these experiments. In J.F. 15 minutes, and in M.B. 30 minutes, after the injection, less than 10 per cent of the blood- $\mathrm{C}^{14}$ is galactose. At the latter time intervals shown, galactose- $\mathrm{C}^{14}$ is even a smaller fraction of the total $\mathrm{C}^{14}$. On the other hand, a substantial amount of the $\mathrm{C}^{14}$ is present as glucose. The nature of the other $\mathrm{C}^{14}$ compound(s) is unknown. For comparison, results are shown in the table for the amount of $\mathrm{C}^{14}$ in blood glucose after glucose-1-C $\mathrm{C}^{14}$ injection. With time a substantial amount of nonglucose- $\mathrm{C}^{14}$ appears in blood, paralleling the results in the galactose experiments.

It is possible to estimate the fraction of injected galactose- $\mathrm{C}^{14}$ circulating as glucose by determining the total $\mathrm{C}^{14}$ in the glucose compartments. This may be calculated if the specific activity of blood glucose and the size of the glucose pool are known. For the 30-minute point of Subject M.B. the specific activity of blood glucose was $52,700 \mathrm{dpm}$ per mmole. Estimating the glucose pools to be 100 mmoles (24), it may be calculated that about 5 million dpm of the 11 million injected are in body glucose pools. This result is consistent with the known pathway of galactose metabolism in which glucose phosphates are intermediates in the conversion of galactose to $\mathrm{CO}_{2}$.

In Figure 3 are shown data of the effect of ethyl alcohol on galactose disappearance from blood after a $20 \mathrm{~g}$ infusion. As has been demonstrated previously by Stenstam (4), alcohol slows this disappearance and this was not corrected by infusion of $5 \mathrm{~g}$ sodium pyruvate, paralleling the results on $\mathrm{C}^{14} \mathrm{O}_{2}$ described previously in the section on $\mathrm{C}^{14} \mathrm{O}_{2}$ excretion. Figure 3 also shows a rise in blood glucose levels after galactose infusion and this is consistent with the data above on the conversion of galactose to glucose. It should be noted that when alcohol is ingested there is little or no increase in blood glucose, as would be expected if alcohol inhibited the conversion of galactose to glucose.

In certain normal individuals $(4,29)$ and in galactosemic infants (30), galactose infusion may cause hypoglycemia. Pozza, Galansino, Hoffeld and Foa (31) have demonstrated that galactose infusion causes increased insulin release from the pancreas. Hyperreactivity to insulin may explain the resultant hypoglycemia in these people. The alternative explanation of Sidbury (32) and Ginsburg and Neufeld (33) that phosphoglucomutase is inhibited by accumulated galactose-1-phosphate, thereby slowing glycogen breakdown to glucose, also should be entertained.

Urinary excretion of $C^{14}$, reducing substance and glucose. Table III presents data on the appearance of $\mathrm{C}^{14}$ in urine. About 3 per cent of the injected $\mathrm{C}^{14}$ was excreted by this route in the tracer studies. In the one study with menthol (Subject M.B.) significantly less $\mathrm{C}^{14}$ appeared in urine. With injection of $20 \mathrm{~g}, 5$ to 8 per cent of the $\mathrm{C}^{14}$ originally given was excreted. Alcohol in-

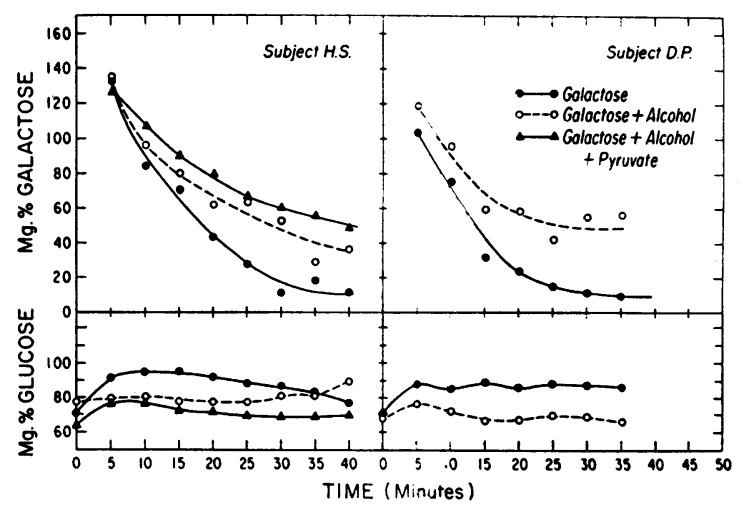

Fig. 3. Disappearance of chemically determined GALACTOSE FROM BLOOD AFTER INFUSION OF $20 \mathrm{G}$ AND THE CONCOMITANT CHANGE IN BLOOD GLUCOSE. 
TABLE III

Urinary excretion of $C^{14}$, reducing substance and glucose oxidase-reacting substance after galactose administration

\begin{tabular}{|c|c|c|c|c|c|c|c|c|c|}
\hline \multirow[b]{3}{*}{ Subj. } & \multirow{3}{*}{$\begin{array}{l}\text { Amt. of } \\
\text { galactose } \\
\text { inj. }\end{array}$} & \multirow[b]{3}{*}{ Drug } & \multirow[b]{3}{*}{ Hours: } & \multicolumn{6}{|c|}{ Dose excreted } \\
\hline & & & & \multicolumn{2}{|c|}{$\mathrm{C}^{14}$} & \multicolumn{2}{|c|}{$\begin{array}{c}\text { Reducing } \\
\text { substances }\end{array}$} & \multicolumn{2}{|c|}{$\begin{array}{c}\text { Glucose oxidase } \\
\text { reactant }\end{array}$} \\
\hline & & & & $0-5$ & $5-24$ & $0-5$ & $5-24$ & $0-5$ & $5-24$ \\
\hline & $g$ & & & \multicolumn{2}{|c|}{$\%$} & \multicolumn{2}{|c|}{$\%$} & \multicolumn{2}{|c|}{$\%$} \\
\hline \multirow{4}{*}{ M.B. } & 0.00106 & \multirow{4}{*}{\multicolumn{2}{|c|}{$\begin{array}{l}\text { None } \\
\text { Menthol } \\
\text { Alcohol, } 10 \mathrm{ml} \\
\text { Pyruvate, } 1 \mathrm{~g}\end{array}$}} & 2.7 & 0.7 & & & & \\
\hline & 0.00106 & & & 0.3 & 0.6 & & & & \\
\hline & 0.00106 & & & 3.2 & 0.5 & & & & \\
\hline & 0.00106 & & & & $3.6^{*}$ & & & & \\
\hline \multirow[t]{2}{*}{ J.F. } & 0.00106 & \multicolumn{2}{|l|}{$\begin{array}{l}\text { None } \\
\text { Progesterone }\end{array}$} & 1.6 & 1.6 & & & & \\
\hline & 0.00106 & \multicolumn{2}{|l|}{ Progesterone } & 1.8 & 0.8 & & & & \\
\hline \multirow[t]{2}{*}{ D.S. } & 20.0 & \multirow{2}{*}{\multicolumn{2}{|c|}{$\begin{array}{l}\text { None } \\
\text { Alcohol } 10 \mathrm{ml}\end{array}$}} & 4.5 & 0.7 & 7.8 & 8.3 & 0.42 & 0.55 \\
\hline & 20.0 & & & 8.6 & 0.5 & 13.3 & 3.1 & 0.20 & 0.34 \\
\hline \multirow[t]{2}{*}{ D.P. } & 20.0 & \multicolumn{2}{|l|}{$\begin{array}{l}\text { Alcohol, } 10 \mathrm{ml} \\
\text { None }\end{array}$} & 7.1 & 0.9 & 11.2 & 3.6 & 0.31 & 2.76 \\
\hline & 20.0 & Alcohol, $20 \mathrm{ml}$ & & 17.7 & 0.7 & 17.6 & 1.4 & 0.53 & 0.96 \\
\hline
\end{tabular}

* Total 24-hour excretion.

gestion essentially doubled the 5 -hour $\mathrm{C}^{14}$ excretion. Reducing substance was assayed in urine of the subjects receiving $20 \mathrm{~g}$ in order to see whether the $\mathrm{C}^{14}$ excreted corresponded to copperreducing sugar. In all but one urine specimen, reducing substance expressed as galactose was greater than the $\mathrm{C}^{14}$. This led to the suspicion that urinary glucose excretion was elevated and that this might account for the discrepancy between reducing substance and $\mathrm{C}^{14}$. The glucose excretion, however (Table III), was not greater than that reported by Froesch and Renold (34) for normal urine, and did not account for the difference between $\mathrm{C}^{14}$ and reducing substance. Froesch and Renold have shown that as much as $1 \mathrm{~g}$ of nonspecific reducing substance expressed as glucose was excreted in 24-hour urine specimens. Since the reducing power of galactose is less than glucose, if the reducing substance is expressed as galactose it would represent well over $1 \mathrm{~g}$ of the sugar or over 5 per cent of the injected $20 \mathrm{~g}$. Thus, the difference between the $\mathrm{C}^{14}$ and galactose expressed as reducing substance could be explained on the basis of nonspecific reducing substance.

In vitro effect of various drugs on galactose oxi-

TABLE IV

In vitro effect of ethanol, menthol, progesterone, and pyruvate on galactose-1-C:t oxidation by human leukocytes and liver*

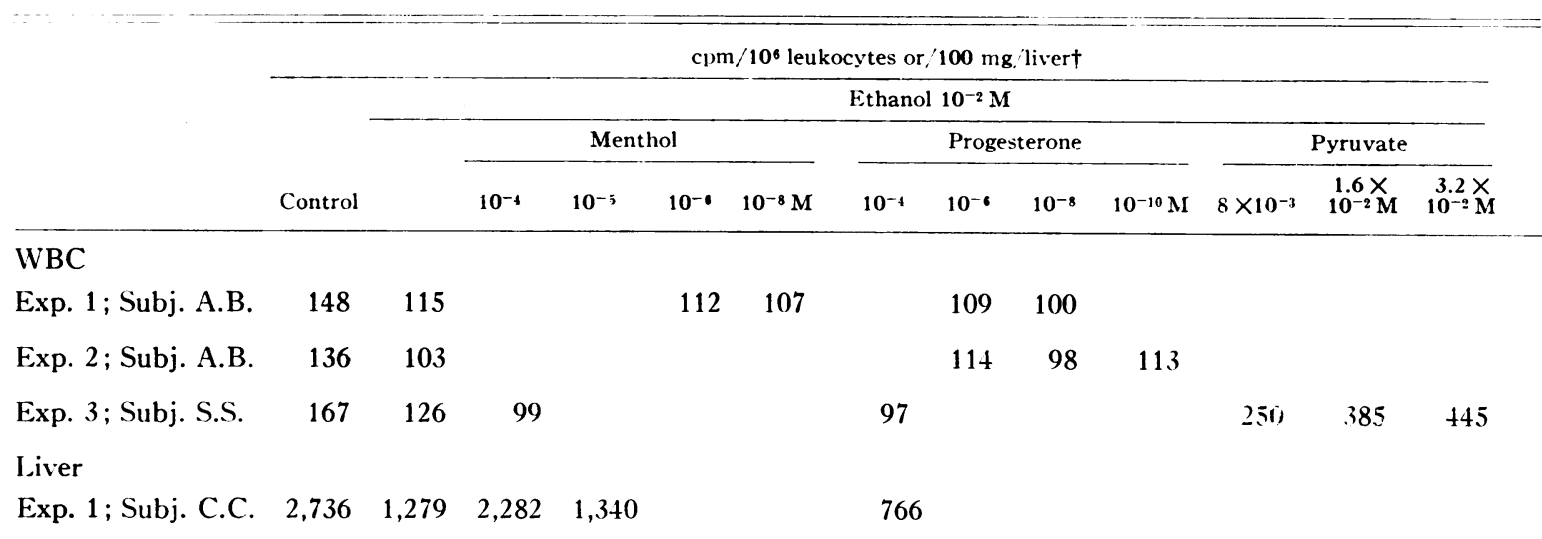

${ }^{*}$ Liver slices were prepared with a Stadie-Riggs microtome and placed in modified Warburg flasks containing $2 \mathrm{ml}$ of Krebs-Ringer bicarbonate buffer and $0.24 \mu \mathrm{c}$ of radioactive galactose. Incubation procedure was similar to that described for the leukocytes (23).

† Leukocyte values are averages of duplicate, and liver the averages of triplicate determinations. 


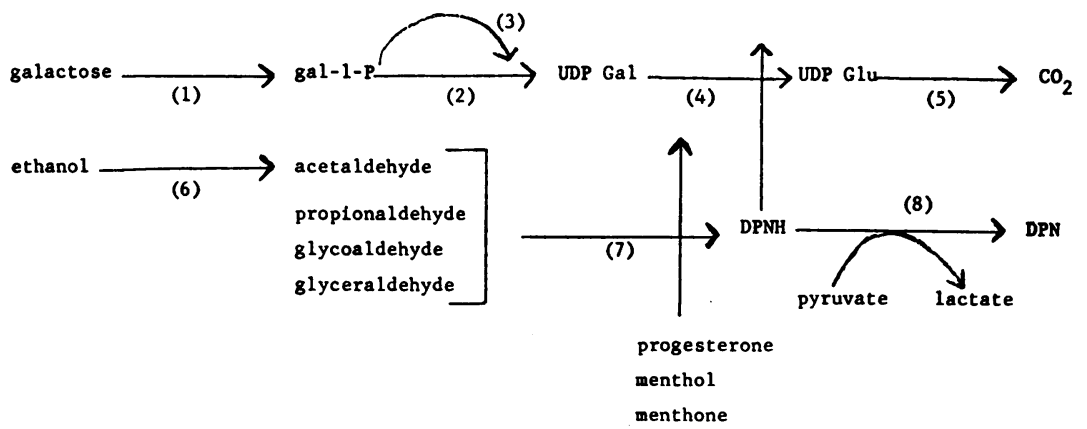

Fig. 4. Schematic Representation of the pathway and factors affecting GALACTOSE METABOLISM. The numbers represent reactions involving the following enzymes: 1 , galactokinase; 2 , galactose-1-P uridyl transferase; 3 , uridinediphosphate galactose (UDPGal) pyrophosphorylase; 4, UDPGal-4-epimerase; 5, uridinediphosphate glucose (UDPGlu) pyrophosphorylase and subsequent enzymes from glucose-1-P to $\mathrm{CO}_{2} ; 6$, alcohol dehydrogenase; 7 , aldehyde dehydrogenase ; 8 , lactic dehydrogenase.

dation by human leukocytes and liver. The inhibition of galactose oxidation in animal liver and intestine by ethanol and certain aldehydes and the reversal of this effect by menthol and progesterone have been reported (10-12). Experiments were performed on human leukocytes to ascertain whether these effects were obtained in human tissues. The data in Table IV demonstrate that ethanol was able to depress galactose oxidation in leukocytes but that menthol and progesterone in a wide range of concentration did not restore the galactose oxidation to normal. On the other hand, pyruvate not only was able to reverse the inhibition caused by ethanol but also caused a stimulation of galactose oxidation above the baseline values. This is in contrast to the lack of effect of pyruvate in the in vivo studies described above. Other experiments with normal hemolysates have shown the inability of menthol and progesterone to reverse the depression of galactose metabolism caused by aldehydic substances (35); but when human liver was employed, $10^{-4} \mathrm{M}$ menthol tended? to negate the ethanol effect. Progesterone at the same concentration appeared to have no such effect.

\section{DISCUSSION}

D-galactose is an important sugar in human nutrition, especially in the young, whose principal food is milk. Milk contains about $5 \mathrm{~g}$ per $100 \mathrm{ml}$ of lactose, which is a disaccharide of glucose and galactose (36). It is not surprising, therefore, to find that normal subjects have the capacity to metabolize large quantities of injected galactose.

The pathway of galactose metabolism has been delineated by Caputto and co-workers and Leloir $(37,38)$ and by Kalckar and Maxwell and associates $(5,6)$. This is schematically shown in Figure 4. Galactose is phosphorylated to form galactose-1-phosphate (gal-1-P) which is then converted to UDPGal by the enzyme gal-1-P uridyl transferase (reaction 2). This is the deficient enzyme in galactosemia. By an alternate route found in yeast (5), mung bean seedlings (39), and in liver (40) (reaction 3), gal-1-P may be transformed to UDPGal. The physiologic role of this pathway in man remains to be assessed. UDPGal is epimerized by UDPGal-4-epimerase to UDP glucose (reaction 4). The latter may undergo pyrophosphorylytic cleavage to glucose-1phosphate which then enters the usual pathway of glucose oxidation to $\mathrm{CO}_{2}$. The present studies show that, in man, galactose is extensively converted to glucose.

Maxwell (41) has described the properties of the UDPGal-4-epimerase enzyme. One of these is marked inhibition by DPNH. DPN is an essential cofactor for the epimerase reaction. It has now become apparent that the level of DPNH in tissue exerts a marked controlling effect on galactose metabolism. Figure 4 summarizes schematically the factors regulating galactose metabolism $(10-12,25,26)$. Ethanol via conversion to 
acetaldehyde, and various aldehydes via conversion to their respective acids by aldehyde dehydrogenase, generate DPNH (reactions 6 and 7). The DPNH inhibits the epimerization of UDPGal which interferes with galactose conversion to glucose. Progesterone, menthol and menthone in the in vitro studies inhibit aldehyde dehydrogenase (reaction 7), thereby preventing the rise in DPNH levels. The effect of ethanol and aldehydes may be reversed by pyruvate conversion to lactate which involves DPNH oxidation to DPN (reaction 8). This takes the "brake" off the epimerase reaction. The importance of the epimerase reaction in the control of galactose metabolism even in the presence of limited amounts of uridyl transferase enzyme (reaction 2) has recently been stressed (42).

The explanation for the lack of an effect in white cells of progesterone and menthol is not readily apparent. Menthol and progesterone are believed to act by affecting the activity of aldehyde dehydrogenase. Maxwell has purified human liver aldehyde dehydrogenase and has found it to be less sensitive to these drugs than are the corresponding enzymes prepared from several species (43). This may be the explanation for an incomplete effect of menthol and the absence of a progesterone effect at the concentrations used in the experiments with human liver. The lack of an effect of the drugs in the white cell could be related to their permeability into the cell. The insensitivity of red cell aldehyde dehydrogenase to these substances (35) tends to suggest, however, that the enzyme present in peripheral blood cells may have characteristics different from the corresponding enzyme present in liver.

Although the role of progesterone and menthol in galactose metabolism in animal tissues in vitro has been elucidated, the mechanism of action of these drugs to stimulate galactose metabolism in subjects with galactosemia remains obscure. The explanation of the latter effect becomes more puzzling in view of the present findings that these drugs do not stimulate galactose metabolism in normal subjects. This raises the question of whether it is mere coincidence that progesterone and menthol in vitro act primarily in a system depressed by aldehyde oxidation and in vivo only in subjects whose metabolism is also depressed.
The knowledge that ethanol ingestion inhibits galactose metabolism has some clinical application. Schwarz has found the accumulation of galactose1-phosphate in cord blood of a newborn galactosemic baby (44) and, along with others (45), has postulated that there may be in utero damage to such a child by transplacental galactose. It might be recommended that when a mother of a known galactosemic child becomes pregnant, in addition to institution of a galactose-free diet, cessation of any ethanol ingestion should be carried out as well.

\section{SUM MARY}

Various quantities of galactose-1-C ${ }^{14}$, when given intravenously to normal human subjects, are rapidly and extensively metabolized to $\mathrm{C}^{14} \mathrm{O}_{2}$. This metabolism is markedly slowed by ingestion of ethanol but is not affected by administration of progesterone, menthol or pyruvate. White blood cell metabolism of galactose in vitro is inhibited by ethanol, but this inhibition is not reversed by menthol or progesterone. Depression by ethanol of galactose oxidation in human liver in vitro is reversed by menthol, as has been observed in other animal species.

\section{REFERENCES}

1. Jankelson, I. R., Segal, M., and Aisner, M. Intravenous galactose liver function test. Amer. J. dig. Dis. 1937, 3, 889.

2. Bassett, A. M., Althausen, T. L., and Coltrin, G. C. A new galactose test for differentiation of obstructive from parenchymatous jaundice. Amer. J. dig. Dis. 1941, 8, 432.

3. Colcher, H., Patek, A. J., Jr., and Kendall, F. E. Galactose disappearance from the blood stream. Calculation of a galactose removal constant and its application as a test for liver function. J. clin. Invest. 1946, 25, 768.

4. Stenstam, T. Peroral and intravenous galactose tests; comparative study of their significance in different conditions. Acta med. scand. 1946, suppl. 177.

5. Kalckar, H. M., Braganca, B., and Munch-Petersen, H. M. Uridyl transferases and the formation of uridine diphosphogalactose. Nature (Lond.) 1953, 172, 1038.

6. Maxwell, E. S., Kalckar, H. M., and Burton, R. M. Galacto-waldenase and the enzymic incorporation of galactose 1-phosphate in mammalian tissues. Biochim biophys. Acta 1955, 18, 444.

7. Kalckar, H. M., and Maxwell, E. S. Some considerations concerning the nature of the enzymic galac- 
tose-glucose conversion. Biochim. biophys. Acta 1956, 22, 588.

8. Isselbacher, K. J., Anderson, E. P., Kurahashi, K., and Kalckar, H. M. Congenital galactosemia, a single enzymatic block in galactose metabolism. Science 1956, 123, 635.

9. Kalckar, H. M., Anderson, E. P., and Isselbacher, K. J. Galactosemia, a congenital defect in a nucleotide transferase. Biochim biophys. Acta 1956, 20, 262.

10. Simon, E. R., Pesch, L. A., and Topper, Y. J. Localization of the steroid hormone effect on galactose metabolism. Biochem. biophys. Res. Com. 1959, $1,6$.

11. Topper, Y. J., Maxwell, E. S., and Pesch, L. A. On the mechanism by which progesterone stimulates galactose metabolism. Biochim. biophys. Acta 1960, 37, 563.

12. Elder, T. D., Segal, S., Maxwell, E. S., and Topper, Y. J. Some steroid hormone-like effects of menthol. Science 1960, 132, 225.

13. Pesch, L. A., Segal, S., and Topper, Y. J. Progesterone effects on galactose metabolism in prepubertal patients with congenital galactosemia and in rats maintained on high galactose diets. J. clin. Invest. 1960, 39, 178.

14. Amatuzio, D. S., Stutzman, F. L., Vanderbilt, M. J., and Nesbitt, $\mathrm{S}$. Interpretation of the rapid intravenous glucose tolerance test in normal individuals and in mild diabetes mellitus. J. clin. Invest. 1953, $32,428$.

15. Fredrickson, D. S., and Ono, K. An improved technique for assay of $\mathrm{C}^{14} \mathrm{O}_{2}$ in expired air using the liquid scintillation counter. J. Lab. clin. Med. 1958, $51,147$.

16. Nelson, N. A photometric adaptation of the Somogyi method for the determination of glucose. J. biol. Chem. 1944, 153, 375.

17. Segal, S., and Foley, J. The metabolism of D-ribose in man. J. clin. Invest. 1958, 37, 719.

18. Blair, A., and Segal, S. The isolation of blood glucose as potassium gluconate. J. Lab. clin. Med. 1960, 55, 959.

19. Van Slyke, D. D., Plazin, J., and Weisiger, J. R. Reagents for the Van Slyke-Folch wet carbon combustion. J. biol. Chem. 1951, 191, 299.

20. Eisenberg, F., Jr. Preparation of the alkaline absorbent for radioactive $\mathrm{CO}_{2}$ in Liquid Scintillation Counting. New York, Pergamon Press, 1958.

21. Wyngaarden, J. B., Segal, S., and Foley, J. B. Physiological disposition and metabolic fate of infused pentoses in man. J. clin. Invest. 1957, 36, 1395.

22. Skoog, W. A., and Beck, W. S. Studies on the fibrinogen, dextran and phytohemagglutinin methods of isolating leukocytes. Blood 1956, 11, 436.

23. Weinberg, A. N., and Segal, S. Effect of galactose-1-phosphate on glucose oxidation by normal and galactosemic leukocytes. Science 1960, 132, 1015 .
24. Segal, S., Berman, M., and Blair, A. The metabolism of variously $C^{14}$-labeled glucose in man and an estimation of the extent of glucose metabolism by the hexose monophosphate pathway. J. clin. Invest. 1961, 40, 1263.

25. Isselbacher, K. J., and McCarthy, E. A. The influence of pyridine nucleotides on galactose-1- $\mathrm{C}^{14}$ oxidation to $\mathrm{C}^{14} \mathrm{O}_{2}$ in vitro. Biochem. biophys. Res. Com. 1959, 1, 49.

26. Isselbacher, K. J., and McCarthy, E. A. Effects of alcohol on the liver: Mechanism of the impaired galactose utilization (abstract). J. clin. Invest. 1960, 39, 999.

27. Smith, M. E., and Newman, H. W. The rate of ethanol metabolism in fed and fasting animals. J. biol. Chem. 1959, 234, 1544.

28. Smith, L. H., Jr., Ettinger, R. H., and Seligson, D. A comparison of the metabolism of fructose and glucose in hepatic disease and diabetes mellitus. J. clin. Invest. 1953, 32, 273.

29. Papper, S., Saxon, L., and Alpert, H. C. The effects of cortisone on the galactose tolerance tests of normal men. J. Lab. clin. Med. 1957, 50, 384.

30. Bruck, E., and Rapoport, S. Galactosemia in an infant with cataracts: Clinical observations and carbohydrate studies. Amer. J. Dis. Child. 1945, 70, 267.

31. Pozza, G., Galansino, G., Hoffeld, H., and Foa, P. P. Stimulation of insulin output by monosaccharides and monosaccharide derivatives. Amer. J. Physiol. 1958, 192, 497.

32. Sidbury, J. B., Jr. Inhibition of phosphoglucomutase with galactose phosphate. Abstracts of papers presented at the National meeting of the Amer. chem. Soc., New York, 1957, p. 27C.

33. Ginsburg, V., and Neufeld, E. F. Inhibition of phosphoglucomutase by galactose-1-phosphate, a possible factor in galactose toxicity. Abstract of papers presented at the National Meeting of the Amer. chem. Soc. 1957, p. 27C.

34. Froesch, E. R., and Renold, A. E. Specific enzymatic determination of glucose in blood and urine using glucose oxidase. Diabetes 1956, 5, 1.

35. Elder, T. D., Segal, S., and Topper, Y. J. Unpublished observations.

36. White, A., Handler, P., Smith, E. L., and Stetten, DeW., Jr. Principles of Biochemistry, 2nd ed. New York, McGraw-Hill, 1959, p. 762.

37. Caputto, R., Leloir, L. F., Trucco, R. E., Cardini, C. E., and Paladini, A. C. The enzymatic transformation of galactose into glucose derivatives. J. biol. Chem. 1949, 179, 497.

38. Leloir, L. F. Enzymatic transformation of uridine diphosphate glucose into galactose derivative. Arch. Biochem. 1951, 33, 186.

39. Neufeld, E. F., Ginsberg, V., Putnam, E. W., Fanshier, D., and Hassid, W. Z. Formation and interconversion of sugar nucleotides by plant extracts. Arch. Biochem. 1957, 69, 602. 
40. Isselbacher, K. J. Evidence for an accessory pathway of galactose metabolism in mammalian liver. Science 1957, 126, 652.

41. Maxwell, E. S. The enzymatic interconversion of uridine diphosphogalactose and uridine diphosphoglucose. J. biol. Chem. 1957, 229, 139.

42. Segal, S., Elder, T. D., and Topper, Y. J. Regulation of galactose metabolism in hemolysates from normal, heterozygous and galactosemic subjects (abstract). J. clin. Invest. 1961, 40, 1081.

43. Maxwell, E. S. Personal communication.

44. Schwarz, V. The value of galactose phosphate determinations in the treatment of galactosaemia. Arch. Dis. Child. 1960, 35, 428.

45. Lockhart, J. D., and Roboz, E. Case of galactosemia identified in a four day old infant by paper chromatographic technic. Pediatrics 1954, 13, 211. 